\title{
The impact of electronic word of mouth on brand image and buying decision: An empirical study in Vietnam tourism
}

\section{Luong, Duy Binh}

Department of Business Administration, Saigon University, Vietnam (duybinh0106@yahoo.com) Vo, Thi Huong Giang

Department of Business Administration and Tourism, Ho Chi Minh City University of Food Industry, Vietnam (vthg0510@gmail.com)

\section{Le, Khoa Huan}

Acting Director of International Training Center, Saigon University,Vietnam (lekhoahuan@sgu.edu.vn)

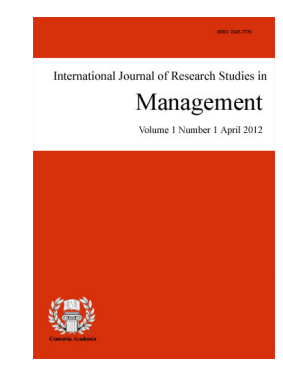

ISSN: $2243-7770$ Online ISSN: 2243-7789

OPEN ACCESS

\section{Abstract}

The purpose of this study is to examine the relationships among electronic Word of mouth (eWOM), brand image, buying intention and buying decision in tourism industry. The questionnaire was distributed to 524 respondents who had experience with social media online. A structural equation modeling is applied to test the relationships among the research variables. The findings show that eWOM has a positive influence on brand image and buying intention. In addition, the results also find the significant relationship between buying intention and buying decision. For managerial implications, this study suggests that managers should keep track of online consumer reviews and give timely solutions.

Keywords: electronic word of mouth; brand image; buying behavior; tourism; Vietnam 


\section{The impact of electronic word of mouth on brand image and buying decision: An empirical study in Vietnam tourism}

\section{Introduction}

In June, 2016, the number of people utilizing Internet all over the world was 3.611 billion. Therein, Asia was accounted for 1,792 billion of total 4.052 billion of people using Internet. Especially, Vietnam is ranked $15^{\text {th }}$ in the world with the number of 49.063 million people (Internet World Stats, 2016). The statistics have shown that Internet plays a significant role as a helpful tool in marketing and communication. There are many users joining one or more online communities directly or indirectly (Albors, Ramos, \& Hervasa, 2008). Hence Internet has referred to a relatively new and increasingly important factor that is global electronic word of mouth (eWOM) (Hennig-Thurau \& Walsh, 2003). Online communities in particular and Internet in general provide not only the opportunities for consumers to share their feelings of product and service, but also the major marketing channels and tools for the companies (Chen \& Xie, 2008; Avery, Resnich, \& Zeckhauser, 1999).

In recent years, Vietnam tourism industry has been increasingly developing. It is estimated to reach $7,943,600$ international visitors with growth rate at $0.9 \%, 57.00$ domestic visitors with growth rate at $48 \%$, and the gross revenue of 338 thousand billion Vietnam dong in 2015 (Ministry of Culture, Sports and Tourism, 2015). Along with the development of Internet and tourists, e-marketing becomes an increasingly important tool which grabs more and more attentions to attract the tourists today. In details, eWOM is mentioned by the way to exchange knowledge between online users. This action has a direct relationship with consumer loyalty; thereby it affects total enterprise value. Thus, the effects of eWOM on consumers are receiving more and more attentions today (Gruen, Osmonbekov, \& Czaplewski, 2006; Hennig-Thurau, Gwinner, Walsh, \& Gremler, 2004). eWOM is different from the traditional advertising because it is considered non-commercial messages created by users. These messages provide the experiences of the previous buyers and affect the other consumer buying decision directly (Godes \& Mayzllin, 2004; Park, Lee, \& Han, 2007). Moreover, those effects may be positive or negative, while satisfied consumers are likely to continue buying the product, and share reviews of good product with the others; dissatisfied consumers tend to remember only the defects of product and spread the reviews of those ones (Richins, 1983). This will cause an influence on consumer buying behavior, especially brand image of the product as well as the company.

Meanwhile, branding is considered one of the important missions to many industries. Strong brands are able to increase consumers' trust toward product and service; and help them get a deeper knowledge of the other hidden factors. Brand image is also the viewpoints and beliefs of consumers about product quality manufactured by companies, especially the company's commitment to the products which are supplied to consumers (Finato, Hadiwidjojo, Aisjah, \& Solimun, 2014; Arslan \& Zaman, 2014). Brand image is an asset, and a good brand image will give a strong competitive advantage through consumer loyalty, product quality and help increase the company's performance. Consumers are more likely to purchase the product with better brand image. Nevertheless, in the process of building up the brand image, only the one which is highly evaluated by users is able to impress the other consumers and stimulate their buying intentions (He, 2013). A positive brand image is proportional to consumer buying intention (Arslan, 2014). Therefore, eWOM and brand image are very important to examine the factors influencing consumer buying behavior.

\section{Literature Review}

$2.1 e-W O M$

Jalilvand, Esfahani, and Samiei (2011) defined word of mouth (WOM) as "a process of sharing opinions and 
information about specific product between customers". WOM is the oral communication between senders and receivers about a product, service or brand. These messages are not sent to receivers with strong ties of commercial purposes (Anderson, 1998; Harrison-Walker, 2001). It is the reason why consumers believe that WOM has higher reliability than commercial advertising (Herr, Kardes, \& Kim, 1991). Thus WOM is a non-commercial source of information which is accepted widely and has a significant influence on formation of consumer proposals and consumer buying decision (Richins, 1983). WOM is especially crucial in case of complex behavior and high risk behavior (Zeithaml, Berry, \& Parasuraman, 1996). It is considered a trustworthy source of information because the sender is usually independent from companies providing product and service; and there is no clearly direct benefit from the person who suggests and support product and service (Silverman, 2001). Along with the strong development of Internet today, Hennig-Thurau et al. (2004) defined eWOM as "any positive or negative statement made by potential, actual, or former customers about a product or company which is made available to multitude of the people and institutes via the Internet".

According to the recent survey of ACNielsen (2007), most of consumers realize that online reivews are as trustworthy as popular websites. Gilly, Graham, Wolfinbarger, and Yale (1998) stated that the lack of useful information to differentiate the products would rise the risk of buying. Some related research has shown that eWOM messages play a significant role in helping consumers get knowledge of the quality of product and service (Chevalier and Mayzlin, 2006). Besides, this information is confirmed useful by consumers who bought product and service before and helps minimize the risks when buying. Hence, their buying intention and decision may be affected more (Chatterjee, 2001). And Chevalier and Mayzlin (2006) pointed out that online communication also affect others' buying behaviors significantly. Although there are a lot of studies about the effects of eWOM on their buying intention, there are just few conducted to research the strong influence of eWOM on brand image, and there is still not any research done in tourism industry yet. As mentioned before, eWOM is one of the factors in online marketing which affects brand image and consumer buying intention. Thereby, these hypotheses are suggested:

$>\quad$ H1: Electronic word-of-mouth has a significant impact on brand image.

$>\quad \mathrm{H} 2$ : Electronic word-of-mouth has a significant impact on consumer buying intention

\subsection{Brand Image}

Brand image is defined by Aaker (2009) as series of brand involvements stored in consumers' minds. Brand image is related to the cognition of a brand, it is created in consumers' memories through brand involvements (Keller, 2011). Brand image is also a consumer's perception about a brand, it leads to consumers' inference of the information regarding to the brand (He, Sha, \& Yang, 2013). Graeff (1970) implied that brand image is similar to personal image of a consumer when consumers associate themselves with the brand. A company with a good brand image is very important in a highly competitive environment (Amstutz, 1970) and building a brand associated with company so that it will remind consumers of the company whenever the product is mentioned and vice versa. Emotions of consumers toward a brand rely on their recognition of that brand (Evanschitzky, Iyer, Plassmann, Niessing, \& Meffert, 2006). Brand image includes comprehensive and overall attributes of product in consumers' minds. Brand image depends on the actual image of company in consumers' minds (Arslan, 2014).

Brand image plays an important role in enhancing company's performance because it is an indirect tool which is able to change consumer buying behavior (Malik, Ghafoor, Iqbal et al., 2013). A positive buying intention is attached to a strong brand image (Khanna, Yan, Tashkin et al., 2007). Therefore, a positive brand image leads to consumer buying intention, while a negative brand image does not cause buying intention. Moreover, Cronin (1992) stated that consumer buying decision totally depends on brand image. Thus brand image create the highest values regarding to the company (Chevalier, 2012). Nevertheless, the number of research measuring the effect of brand image on consumer buying intention is still limited. Thus authors suggest 
Luong, D. B., Vo, T. H. G., \& Le, K. H.

the following hypothesis based on above arguments:

$>$ H3: Brand image has a significant impact on consumer buying intention.

\subsection{Consumer Buying Intention and Consumer Buying Decision}

An intention behavior is defined as "subjective probability that he or she will engage in a given behavior" (Committee on Communication for Behavior Change in the 21st century, 2002). Lin (2009) defined buying intention as consumers' probable reaction when they buy a specific product. $\mathrm{He}$ and $\mathrm{Hu}$ (2008) explained that buying intention is the transaction after consumer has an overall evaluation of the product, such as attitude. Consumers' recommendations are associated with the positive buying intention, and affect directly consumers' choice (Chang \& Chin, 2010). According to Armstrong and Kotler (2003), "consumer buying behavior refers to the buying behavior of final consumers, individuals and household who buy goods and services for personal consumption". Consumer buying process includes five stages: need recognition, information search, and evaluation of alternatives, purchase decision and post purchase behavior (Armstrong \& Kotler, 2010). Theory of planned behavior (TPB) is applied to investigate the relationship between belief, attitude, intention and behavior. TPB said that the usage of actual behavior is the result of intention. According to theory of rational action, the stronger intention of a person leads to a specific action, the more likely a specific behavior is conducted (Ajzen, 1991). According to Brown (2003), a consumer who intends to buy a certain product will show a higher aibility to buy than those who do not have intention to buy. In addition, the higher intention consumers have to buy the product, the more it motivates them to their buying decisions (Luong, Cho, \& Vo, 2016). Based on these evidences, the hypothesis H4 is suggested:

$>\quad$ H4: Consumer buying intention has a positively and significantly impact on consumer buying decision

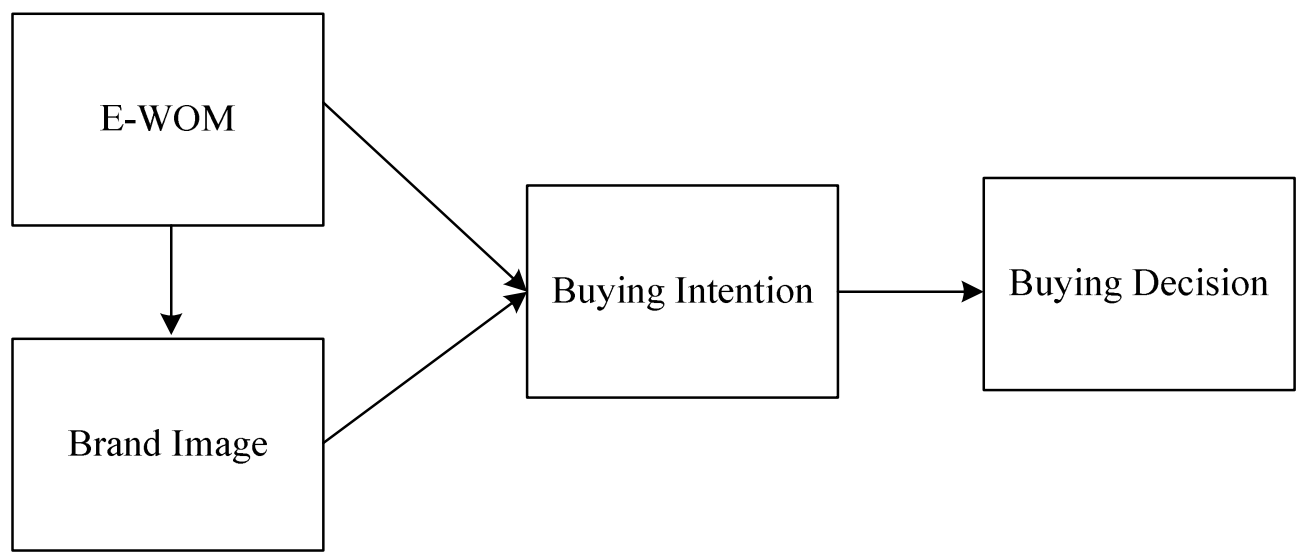

Figure 1. Conceptual model

\section{Methodology}

The survey in this study was developed based on previous studies, after being checked and edited, it consists of five parts: eWOM, brand image, buying intention, buying decision and demographic information. In eWOM, respondents were asked about the use of online communication with six questions were used by eWOM Bambauer-Sachseand and Mangold (2011). For the brand image, five questions were based on the research of Davis, Golicic, and Marquardt (2009); Cho, Luong, Vo, and Lee (2016). In the buying intention, three questions were adopted from Shukla (2010), respondents were asked about the intention on the selection of tourism products and services. The next section, three questions were used to asked respondents about buying decision 
Impact of electronic word of mouth on brand image and buying decision: An empirical study in Vietnam tourism behavior, based on research Luong et al. (2016). Scale of "eWOM", "brand image", "buying intention" and "buying decisions" as measured by the five-point Likert scale, ranging from completely disagree (1) to totally agree (5). The final part of the survey is to collect personal information about respondents such as age, sex, education and monthly income

This study used snowball sampling method to collect data at Ho Chi Minh City. Respondents were required with an online purchasing experience. 530 surveys were delivered to respondents and 524 questionnaires were obtained. There are 96 percent responses rate from those who agree to answer. The data collected was analyzed by using SPSS and AMOS software. SPSS software uses to test reliability, descriptive statistic, exploratory factor analysis, correlation, t-test, ANOVA; while AMOS uses to examine linear relationships among latent (unobserved) variables and manifest (observed) variables by tests of structure equation modeling (SEM). The indicators measure was used to assess the suitability of structural models include GFI, RMSEA, IFI, TLI, and CFI.

\section{Results and Discussion}

\subsection{Results}

Table 1

Demographics information of respondents

\begin{tabular}{|c|c|c|c|c|}
\hline \multicolumn{2}{|c|}{ Characteristics } & Frequency & Percent & Cumulative Percent \\
\hline \multirow[t]{2}{*}{ Gender } & Male & 208 & 39.7 & 39.7 \\
\hline & Female & 316 & 60.3 & 100.0 \\
\hline \multirow{4}{*}{ Age } & $18-24$ & 246 & 46.9 & 46.9 \\
\hline & $25-30$ & 142 & 27.1 & 74.0 \\
\hline & $31-40$ & 76 & 14.5 & 88.5 \\
\hline & $41-55$ & 60 & 11.5 & 100.0 \\
\hline \multirow{4}{*}{ Occupation } & Student & 222 & 42.4 & 42.4 \\
\hline & Officer & 212 & 40.5 & 82.8 \\
\hline & Businessman & 58 & 11.1 & 93.9 \\
\hline & Others & 32 & 6.1 & 100.0 \\
\hline \multirow{4}{*}{ Monthly income } & $\$ 100-\$ 250$ & 110 & 21.0 & 21.0 \\
\hline & $\$ 251-\$ 400$ & 210 & 40.1 & 61.1 \\
\hline & $\$ 401-\$ 550$ & 134 & 25.6 & 86.6 \\
\hline & More than $\$ 550$ & 70 & 13.4 & 100.0 \\
\hline \multirow{5}{*}{ Education } & High school & 74 & 14.2 & 14.9 \\
\hline & Bachelor & 282 & 53.8 & 67.9 \\
\hline & Master & 118 & 22.5 & 90.5 \\
\hline & Ph.D. & 22 & 4.2 & 94.7 \\
\hline & Others & 28 & 5.3 & 100.0 \\
\hline \multirow{3}{*}{$\begin{array}{l}\text { Frequency of internet } \\
\text { usage in a week }\end{array}$} & 6-10 hours & 12 & 2.3 & 2.3 \\
\hline & $11-20$ hours & 69 & 13.2 & 15.5 \\
\hline & 21 hours or more & 443 & 84.5 & 100.0 \\
\hline
\end{tabular}

Of a total sample of 524 respondents, 60.3 percent (316) were female and 39.7 percent (208) were male. The majority ages of respondents were 18-24 years old (46.9 percent), 25-30 (27.1 percent), 31-40 (14.5 percent) and 41-55 (11.5 percent). The monthly income classification was mostly distributed among the \$251-\$400 (40.1 percent), followed by $\$ 100-\$ 250$ (21 percent), \$401-\$550 (25.6 percent) and more than $\$ 550$ (13.4 percent). The majority of respondents' education was bachelor degree (53.8 percent), followed by master degree (22.5 percent). 85.5 percent of respondents used internet 21 hours or more in week. Descriptive statistics are showed in table 1.

Table 4 shows the standardized regression line pointed the direct influence of the latent variable. Theoretical model of four factors have Chi-square $\left(\mathrm{X}^{2}\right)$ is $272.465\left(\mathrm{df}=115, \mathrm{X}^{2} / \mathrm{df}=2.369, p=0.000\right)$. The model fit 
Luong, D. B., Vo, T. H. G., \& Le, K. H.

indices of the structural model with the goodness of fit index ( $\mathrm{GFI}=0.942)$, comparative fit index (CFI $=0.966$ ), the comparative fit index (NFI $=0.942)$, Tucker-Lewis index (TLI $=0.959)$, with 1 being the maximum appropriate indicators of this research model. Finally, RMSEA $=0.051$, with values $<0.08$ is very fit. The result pointed out that all indicators show that the model structure is appropriate.

Table 2

Descriptive statistics of constructs

\begin{tabular}{lcccc}
\hline \multicolumn{1}{c}{ Constructs } & Item & $\begin{array}{c}\text { Standardized } \\
\text { Loading }\end{array}$ & Mean & SD \\
\hline & EWOM1 & 0.861 & 3.27 & .962 \\
Electronic Word of Mouth (EWOM) & EWOM2 & 0.790 & 3.32 & .963 \\
Cronbach's $\alpha=0.842$ & EWOM3 & 0.861 & 3.34 & .963 \\
$(\mathrm{CR}=0.845$, AVE $=0.574)$ & EWOM4 & 0.761 & 3.41 & .973 \\
& EWOM5 & 0.706 & 3.32 & .978 \\
& EWOM6 & 0.511 & 3.46 & .991 \\
\hline & BI1 & 0.839 & 3.88 & .890 \\
Brand Image (BI) & BI2 & 0.885 & 3.77 & .912 \\
Cronbach's $\alpha=0.912$ & BI3 & 0.851 & 3.78 & .897 \\
(CR =0.913, AVE =0,676) & BI4 & 0.885 & 3.82 & .931 \\
& BI5 & 0.820 & 3.72 & .974 \\
\hline Buying Intention (PI) & BI1 & 0.874 & 3.53 & 1.028 \\
Cronbach's $\alpha=0.788$ & BI2 & 0.836 & 3.64 & .926 \\
(CR =0. 789, AVE $=0.556)$ & BI3 & 0.730 & 3.74 & .929 \\
\hline Buying Decision (BD) & BD1 & 0.849 & 3.87 & .924 \\
Cronbach's $\alpha=0.873$ & BD2 & 0.916 & 3.87 & .991 \\
(CR =0.874, AVE =0.699) & BD3 & 0.912 & 4.06 & .903 \\
\hline
\end{tabular}

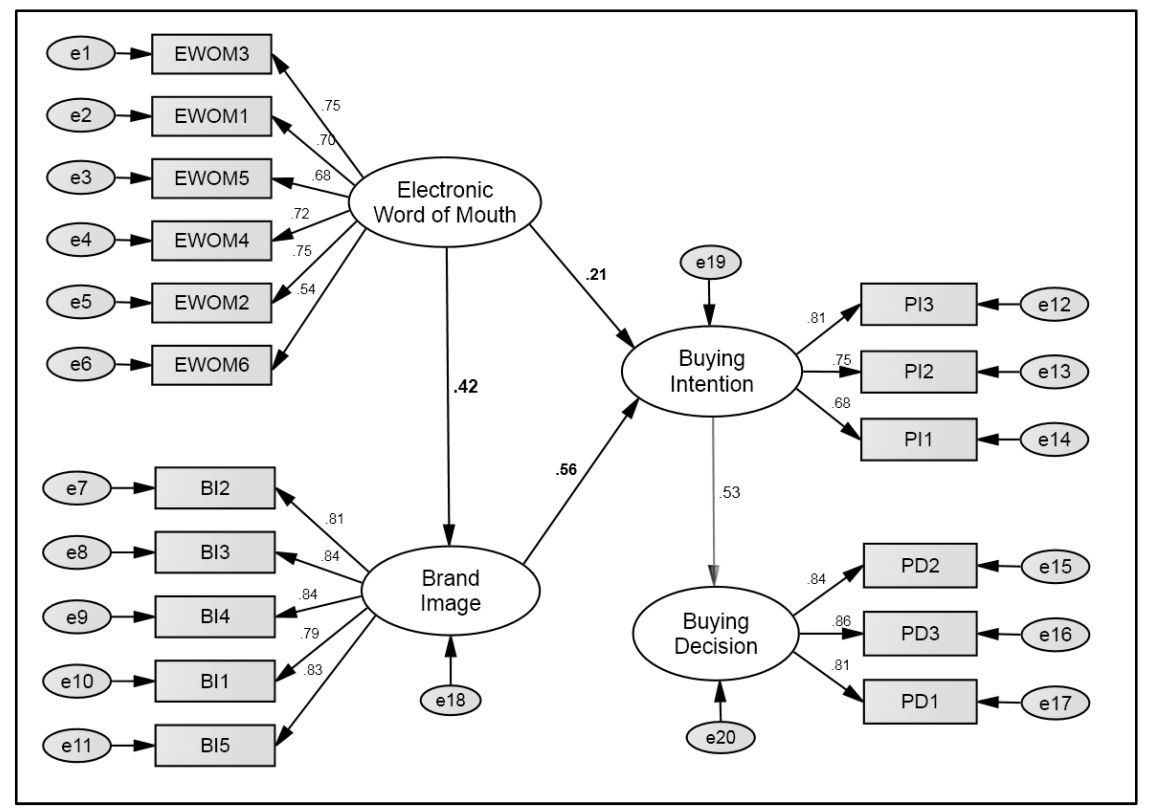

Figure 2. Standardized regression coefficients

The result shows the relationship among four variables which are eWOM, brand image, buying intention and buying decision (table 3). There are four relationships which found to be significant at the level of 0.01 . e-WOM had a significantly positive impact on brand image, with $\beta=0.42, p=0.000$. e-WOM also had a strong positive effect on consumer buying intention $(\beta=0.21, p=0.000)$. Brand image has positive impact on consumer buying intention, with $\beta=0.53, p=0.000$. Finally, buying intention strongly positive effects on 
Impact of electronic word of mouth on brand image and buying decision: An empirical study in Vietnam tourism buying decision $(\beta=0.57, p=0.000)$. As the research results indicated that all hypotheses were supported.

$>$ eWOM has a strong positive impact on brand image

$>\quad$ eWOM has a positive impact on buying intention

$>$ Brand image influence positively buying intention

$>\quad$ Buying intention has positive and significant impact on buying decision

Table 3

Maximum likelihood estimates for research model $(N=524)$

\begin{tabular}{llccc}
\hline \multicolumn{1}{c}{ Independent Variable } & \multicolumn{1}{c}{ Dependent Variable } & Estimate & $\begin{array}{c}\text { Standardized } \\
\text { Estimated }\end{array}$ & $p$-value \\
\hline Electronic Word of Mouth & Brand Image & 0.43 & 0.42 & $* *$ \\
Electronic Word of Mouth & Buying Intention & 0.20 & 0.21 & $* *$ \\
Brand Image & Buying Intention & 0.53 & 0.56 & $* *$ \\
Buying Intention & Buying Decision & 0.57 & 0.53 & $* *$ \\
\hline
\end{tabular}

Table 4

Model fit statistics

\begin{tabular}{lcc}
\hline \multicolumn{1}{c}{ Structural model } & Fit statistics & Acceptable Fit \\
\hline Chi-square $\left(\mathrm{X}^{2)}\right.$ & 272.465 & \\
Degree of freedom $(\mathrm{df})$ & 115 & \\
$\mathrm{p}$-value & $<0.05,<0.01$ & \\
$\mathrm{X}^{2} / \mathrm{df}$ & 2.369 & $1.0-3.0$ \\
GFI & 0.942 & $>0.90$ \\
NFI & 0.942 & $>0.90$ \\
CFI & 0.966 & $>0.90$ \\
TLI & 0.959 & $>0.90$ \\
RMR & 0.44 & $<0.50$ \\
RMSEA & 0.051 & $<0.08$ \\
\hline
\end{tabular}

\section{Discussion}

The purpose of this research is to evaluate the effect of eWOM, brand image to customers' buying intention and the connection between customers' intention and decisions in tourism. Results of this research will provide insightful information for managers, marketers. In this research, eWOM is identified as it influences strongly to brand image and Vietnamese consumers' intention when choosing tourism products. This means whenever customers want to find a brand or have buying intention one service/product, they would pay attention to eWOM, for example, comments about services/products on the internet. In previous studies, authors said that eWOM have important role in creating brand image (Jalivalcand \& Samiei, 2012; Torlak, Ozkara, Tiltay et al., 2014). However, Jalivalcand et al. (2012) and Torlak et al. (2014) said that eWOM have no effect on consumer' buying intention.

Mentioned brand image, this research provide perceptive information which is shown brand image has positive influence on customers' buying intention. Brand image has major and positive role in creating buying intention of customers which is found as a consensus among some author (Jalivalcand et al., 2012; Torlak et al., 2014; Finato et al., 2014; Cho et al., 2016). As the result, brand image affect Vietnamese consumers' believes and choices. Whenever choosing tourism products, customers choose brands which have better image. Besides factors such as perennial brand, quality, price of products, services, consumers also depend on online evaluations from other customers. 
While previous research is limited to point out effect of eWOM and brand image to buying intention (Jalivalcand et al., 2012; Torlak et al., 2014), this research confirms and expands previous research by examining influence of buying intention to consumer buying decision. According to Theory of reasoned action individual stronger intention lead to specific action, and specific action would be performed (Ajzen, 1991). According to Luong \& et al, 2015, the buying intention of customer stronger, the more it motivates them to buying decision. Similar to other research, this paper shows that buying intention has significant impact on buying decision. This point was verified in research of We, Ariff, Zakuan, and Tajudin (2014), but not about tourism. Result of that research proved that when customers have intention in buying any tourism services, they probably decide to buy that products or services.

\section{Conclusion}

\subsection{Summary}

Nowadays, the development of social network such as Facebook, Instagram, Twitter, Pinterest as well as mobile apps like Zalo, What's app, Line, consumers can share their experience about products/services and it becomes more popular. Moreover, internet can be used everywhere in anytime, hence, it is easy to accept, read and write reviews, comment on the internet. Therefore, question is given as what is the role of electronic word of mouth to buying behavior of Vietnamese Consumer. In circumstance of electronic word of mouth, brand image does not under consideration. Therefore, this paper relies on other previous research and gives expanding information related to eWOM, brand image, buying intention and buying decision in tourism. As a result, eWOM has huge and positive impact on brand image. Besides, eWOM and brand image have certain influence on buying intention. Then, buying intention has strongly effect on buying decision of customers in tourism. Especially, this result has important meanings to marketers, managers in tourism. Moreover, this paper's results relate to brand image through internet would become new stages for managers who want to improve their brand images.

\subsection{Managerial Implication}

By using smart phones and internet, consumers can read reviews, comment directly about products/services that they want to buy, that impacts strongly consumers' buying decisions at shopping time. Nowadays, before customers bought any products, they would find out information about brand image, prices on the internet, especially, read carefully comments, and reviews on both online and traditional word of mouth. Therefore, managers can run events that allow customers to try some tourism products/services or cooperate with other companies giving travel tours as shopping promotions. That can create clearly impression about products and encourage online word of mouth from customers after trying products. Good comments and reviews from consumers would disseminate widely on internet. That makes brand image of tourist companies or travel spots and cooperated companies have a place in customers' hearts.

Moreover, companies need to invest more in products quality to create fierce competition in developed and integrated trend today. That is steady footages for companies running business in long-term and improves reputation to customers. The model of Zeithaml et al. (1996) suggests that services quality affects behaviors and positive intention including WOM, buying intention, acts of complaints and price sensitive. Besides improving products quality, companies need to be aware of risks from eWOM, particularly business without high brand image. Negative impacts from online word of mouth would be increase and spread in netizen. When consumers read bad reviews, comments about services/products of tourism companies or travel places, which deeply affects brand image of that companies. Moreover, that will influence on buying intention and buying decision of customers.

Nowadays, using internet surveys, managers know customers' belief in services/products of companies and how effective their staff via electric word of mouth. Managers should pay attention to customers' satisfaction to 
Impact of electronic word of mouth on brand image and buying decision: An empirical study in Vietnam tourism handle negative comments, reviews immediately, to avoid bad effects on brand image as well as buying intention and decision to buy tourism's products/services of new potential customers. Moreover, manager should have directly contact with staff to receive negative feedback from consumers about products/services then examining that information. If dissatisfaction of customers is real, managers should have immediate actions to gain customers' belief such as sending apology letters which including supports services in the future. However, if negative feedbacks were unreal in order to compete unfairly, managers should plan stronger projects for building brand image and eWOM to improve customers' belief.

Especially, marketers should promote brand image continually by articles, vibrant images, attracting customers by promotion campaigns, events, and gaining their belief from feedback. Good evaluations from customers, in which, they had experienced high-quality services, are the best indicator for a company's brand image. A company, if it had been able to persuade customers to accept the company's brand images, has a higher chance in keeping customers from using its tourism services/products.

This research has some limitations; first, the variables of price, quality, belief etc are not mentioned in paper. This means result of research does not included all aspects related to buying intention and buying decision of customers. In later research, author should expand research models, combine more factors to examine consumers' buying intention and decision. Second, this paper focuses Vietnamese customer, in future research, foreigners can be mentioned to compare different cultures effect. Third, this research is mainly about tourism, and it can apply to other industries and services in other industry.

\section{References}

Aaker, D. A., \& Joachimsthaler, E. (2009). Brand leadership: Building assets in an information economy. Simon and Schuster.

Aaker, J. L. (1997). Dimensions of brand personality. Journal of Marketing Research, 34(3), 347-356. https://doi.org/10.2307/3151897

ACNielsen. (2007). Trust in advertising: A global Nielsen consumer report, October. New York: AC Nielsen.

Ajzen, I. (1991). The theory of planned behavior. Organizational Behavior and Human Decision Process, 50(2), 179-211. https://doi.org/10.1016/0749-5978(91)90020-T

Albors, J., Ramos, J. C., \& Hervasa, J. L. (2008). New learning network paradigms: communities of objectives, crowd sourcing, wikis and open source. International Journal of Information Management, 28(3), 194-202. https://doi.org/10.1016/j.ijinfomgt.2007.09.006

Amstutz, A. E. (1970). Computer simulation of competitive market response. MIT Press Books.

Anderson, E. W. (1998). Customer satisfaction and word of mouth. Journal of Service Research, 1(3), 5-17. https://doi.org/10.1177/109467059800100102

Armstrong, G., \& Kotler, P. (2003). Marketing (6th ed.). Upper Saddle River, NJ: Pearson Prentice Hall.

Arslan, M. (2014). Impact of brand image and service quality on consumer purchase intention: A study of retail store in Pakistan. Research on Humanities and Social Sciences, 4(22), 98-105.

Arslan, M., \& Zaman, R. (2014). Impact of brand image and service quality on consumer purchase intention: a study of retail store in Pakistan. Research on Humanities and Social Sciences, 4(22).

Avery, C., Resnich, P., \& Zeckhauser, R. (1999). The market for evaluations. American Economic Review, 89(3), 564-584. https://doi.org/10.1257/aer.89.3.564

Bambauer-Sachse, S., \& Mangold, S. (2011). Brand equity dilution through negative online word-of-mouth communication. Journal of Retailing and Consumer Services, 18, 38-45. https://doi.org/10.1016/j.jretconser.2010.09.003

Brown, M. (2003). Buying or browsing? An exploration of shopping orientations and online purchase intention. European Journal of Marketing, 37(11/12), 1666-1684. https://doi.org/10.1108/03090560310495401

Chang, C. C., \& Chin, Y. C. (2010). The impact of recommendation sources on online purchase intentions: the moderating effects of gender and perceived risk. World Academy of Science, Engineering and Technology, 66(June), 111-114. 
Luong, D. B., Vo, T. H. G., \& Le, K. H.

Chen, Y., \& Xie, J. (2008). Online consumer review: Word-of-mouth as a new element of marketing communication mix. Management Science, 54(3), 477-91. https://doi.org/10.1287/mnsc.1070.0810

Chevalier, J. A., \& Mayzlin, D. (2006). The effect of word of mouth on sales: online book reviews. Journal of Marketing Research, 43(3), 345-54. https://doi.org/10.1509/jmkr.43.3.345

Chevalier, M., \& Mazzalovo, G. (2012). Luxury brand management: A world of privilege. Wiley. https://doi.org/10.1002/9781119199168

Cho, J., Luong, D. B., Vo, T. H. G., \& Lee, W. C. (2016). Vietnamese consumer behavior of cosmetics products: Effects of extrinsic cues. In the Proceedings of 37 th International business research conference (pp. 1-21). Las Vegas, USA.

Committee on Communication for Behavior Change in the 21st Century. (2002). Speaking of health: Assessing health communication strategies for diverse populations. Washington, DC: National Academies Press.

Cronin Jr, J. J., \& Taylor, S. A. (1992). Measuring service quality: A reexamination and extension. The Journal of Marketing, 55-68. https://doi.org/10.2307/1252296

Davis, D. F., Golicic, S. L., \& Marquardt, A. (2009). Measuring brand equity for logistics services. International Journal of Logistics Management, 20(2), 201-212. https://doi.org/10.1108/09574090910981297

Evanschitzky, H., Iyer, G. R., Plassmann, H., Niessing, J., \& Meffert, H. (2006). The relative strength of affective commitment in securing loyalty in service relationships. Journal of Business Research, 59(12), 1207-1213. https://doi.org/10.1016/j.jbusres.2006.08.005

Finato, A. Y. A., Hadiwidjojo, D., Aisjah, S., \& Solimun. (2014). The influence of brand image on purchase behaviour through brand trust. Business Management and Strategy, 5(2), 1-19.

Gilly, M. C., Graham, J., Wolfinbarger, M. F., \& Yale, L. J. (1998). A dyadic study of interpersonal information search. Journal of the Academy of Marketing Science, 26(2), 83-100. https://doi.org/10.1177/0092070398262001

Godes, D., \& Mayzlin, D. (2004). Using online conversations to study word-of-mouth communication. Marketing Science, 23(4), 545-60. https://doi.org/10.1287/mksc.1040.0071

Graeff, T. R. (1997). Consumption situations and the effects of brand image on consumers' brand evaluations. Psychology \& Marketing, 14(1), 49-70. https://doi.org/10.1002/(SICI)1520-6793(199701)14:1<49::AID-MAR4>3.0.CO;2-O

Gruen, T. W., Osmonbekov, T., \& Czaplewski, A. J. (2006). eWOM: The impact of customer-to-customer know-how exchange on customer value and loyalty. Journal of Business Research, 59(4), 449-56. https://doi.org/10.1016/j.jbusres.2005.10.004

Hair, J. F., Anderson, R. E., Tatham, R. L. \& Black, W. C. (1998), Multivariate data analysis (5th ed.). Prentice Hall, Upper Saddle River, NJ.

Harrison-Walker, L. J. (2001). The measurement of word-of-mouth communication and an investigation of service quality and customer commitment as potential antecedents. Journal of Service Research, 4(1), 60-75. https://doi.org/10.1177/109467050141006

He, M., Sha, Z., \& Yang, Y. (2013). An empirical study on impacts of brand image of travel agencies on customer purchase intentions. Paper presented in the 2013 2nd International conference on systems engineering and modeling. https://doi.org/10.2991/icsem.2013.70

He, Y. C., \& Hu, H. H. (2008). A study of consumers' purchase intentions toward retail store brands in the food sector. Journal of Hospitality and Home Economics, 5(3), 63-84.

Hennig-Thurau, T., \& Walsh, G. (2003). Electronic word-of-mouth: motives for and consequences of reading customer articulations on the internet. Journal of Electronic Commerce, 8(2), 51-74.

Hennig-Thurau, T., Gwinner, K. P., Walsh, G., \& Gremler, D. D. (2004). Electronic word-of-mouth via consumer-opinion platforms: what motivates consumers to articulate themselves on the internet?. Journal of Interactive Marketing, 18(1), 38-52. https://doi.org/10.1002/dir.10073

Herr, P. M., Kardes, F. R., \& Kim, J. (1991). Effects of word-of-mouth and product-attribute information on persuasion: An accessibility-diagnosticity perspective. Journal of Consumer Research, 17(4), 454-462. https://doi.org/10.1086/208570

Internet World Stats. (2016). Internet users, Facebook subscribers and population statistics for 35 countries and 
Impact of electronic word of mouth on brand image and buying decision: An empirical study in Vietnam tourism regions in Asia. Retrieved from http://www.internetworldstats.com/stats3.htm

Internet World Stats. (2016). World internet users and 2016 population stats. Retrieved from http://www.internetworldstats.com/stats.htm

Jalilvand, M. R., Esfahani, S. S., \& Samiei, N. (2011). Electronic word-of mouth: Challenges and opportunities. Procedia Computer Science, 3, 42-46. https://doi.org/10.1016/j.procs.2010.12.008

Jalivalcand, M. R., \& Samiei, N. (2012). The effect of electronic word of mouth on brand image and purchase intention: An empirical study in the automobile industry in Iran. Marketing Intelligence \& Planning, 30(4), 460-476. https://doi.org/10.1108/02634501211231946

Keller, K. L., Parameswaran, M., \& Jacob, I. (2011). Strategic brand management: Building, measuring, and managing brand equity. Pearson Education.

Khanna, D., Yan, X., Tashkin, D. P., Furst, D. E., Elashoff, R., Roth, M. D., \& Seibold, J. R. (2007). Impact of oral cyclophosphamide on health-related quality of life in patients with active scleroderma lung disease: Results from the scleroderma lung study. Arthritis \& Rheumatism, 56(5), 1676-1684. https://doi.org/10.1002/art.22580

Lin, C. W. (2009). The influence of the original brand attitude, perceived fit, and sales promotion on customers' brand attitudes and purchase intentions of the brand extensions. Journal of Environmental and Management, 4(2), 1-30.

Luong, D. B., Cho, J., \& Vo, T. H. G. (2016). The impact of mobile advertising on Vietnamese consumer buying decision. International Journal of Research Studies in Management, 5(1), 3-18.

Malik, M. E., Ghafoor, M. M., Iqbal, H. K., Ali, Q., Hunbal, H., Noman, M., \& Ahmad, B. (2013). Impact of brand image and advertisement on consumer buying behavior. World Applied Sciences Journal, 23(1), 117-122.

Medsker, G. J., Williams, L. J., \& Holahan, P. J. (1994). A review of current practices for evaluating causal models in organizational behavior and human resources management research. Journal of Management, 20, 439-464. https://doi.org/10.1177/014920639402000207

Ministry of Culture, Sports and Tourism. (2015). Chỉ tiêu, số liệu cơ bản ngành văn hóa, thể thao và du lịch năm 2015 [Targets, basic data of culture, sports, and tourism in 2015]. Retrieved from http://www.bvhttdl.gov.vn/vn/thong-tin-thong-ke/0/21/index.html

Park, D. H., Lee, J., \& Han, I. (2007). The effects of on-line consumer reviews on consumer purchasing intention: the moderating role of involvement. International Journal of Electronic Commerce, 11(4), 125-48. https://doi.org/10.2753/JEC1086-4415110405

Richins, M. (1983). Negative word-of-mouth by dissatisfied consumers: A pilot study. Journal of Marketing, 47(1), 68-78. https://doi.org/10.2307/3203428

Silverman, G. (2001). The secrets of word-of-mouth marketing: How to trigger exponential sales through runaway word-of-mouth. New York, NY: Amazon Books.

Torlak, O., Ozkara, B. Y., Tiltay, M. A., Cengiz, H., \& Dulger, M. F. (2014). The effect of electronic word of mouth on brand image and purchase intention: An application concerning cell phone brands for youth consumers in Turkey. Journal of Marketing Development and Competitiveness, 8(2), 61-68.

We, C. S., Ariff, M. S. B., Zakuan, N., \& Tajudin, M. N. M. (2014). Consumers perception, purchase intention and actual purchase behavior of organic food products. Review of Integrative Business and Economics Research, 3(2).

Zeithaml, V., Berry, L. L., \& Parasuraman, A. (1996). The behavioral consequences of service quality. Journal of Marketing, 60(2), 31-46. https://doi.org/10.2307/1251929 
Luong, D. B., Vo, T. H. G., \& Le, K. H. 